\title{
Perbaikan Kualitas dan Dekontaminasi Mikroba Kedelai Edamame Dengan Teknik Ozonated Water
}

\author{
Improved Quality and Decontamination of \\ Microorganisms on edamame soybeans With \\ Ozonated Water Technique
}

\author{
Abi Bakri ${ }^{1}$, Wahyu Suryaningsih ${ }^{1}$, Budi Hariono ${ }^{2}$, Sri Hartatik $^{3}$ \\ ${ }^{1}$ Teknologi Industri Pangan, Teknologi Pertanian, Politeknik Negeri Jember \\ ${ }^{2}$ Keteknikan Pertanian, Teknologi Pertanian, Politeknik Negeri Jember \\ ${ }^{3}$ Jurusan Agroteknologi, Fakultas Pertanian Universitas Negeri Jember \\ ${ }^{1}$ E-mail: abipolijelgmail.com
}

\begin{abstract}
Quality, contamination of microorganisms and pesticide residues is a major requirement in edamame export trade. Ozonated water technique is expected to replace the use of chlorine in suppressing microorganism contamination and maintaining quality. Research objectives: a) To determine the effect of various conditions of ozone concentration on quality and contamination of microorganisms on edamame soybeans, b) Comparing the effectiveness of Ozonated Water technique with chlorination, and c) Obtain optimal Ozonated Water method in maintaining quality and eliminating contaminants of microorganisms. The research method used CFRD with 2 Factors ie Factor A of ozone concentration $(0,3,6$ and 9 ppm) and Factor B is Chlorine concentration $(0,100$ and $175 \mathrm{ppm}$ ) repeated 3 times. The statistical analysis used the Analysis of Variance with the $F$ test and the further difference statistical test of a) the organoleptic quality with Hedonic test includes color, aroma, sweet taste and Hedonic Quality Test for Foreign Odor b) microbiological examination (Total Plate Count). The results are: a) Ozone and chlorine treatment can reduce the total content of edamame microorganisms compared to control, and ozone treatment is more effective in reducing total microbial than chlorine; b) Ozone or Chlorine treatment has no effect on hedonic color and sweetness value in edamame; and c) Ozone treatment may decrease the value of edamame aroma compared with chlorine control and treatment, although in fact Ozone treatment does not contribute to foreign odors or chemical odors to edamame. The conclusion of Ozonated water technique can significantly decrease microorganisms contamination and maintain the color quality, sweet taste and donate foreign odors in edamame.
\end{abstract}

Keywords-Ozonated Water, Chlorine, Edamame, Microorganisme

\section{PENDAHULUAN}

Produk edamame segar ekspor melalui serangkaian proses: (a) tahapan penerimaan bahan baku, (b) blower, (c) grading, (d) pencucian I, (e) sortasi, (f) pencucian II, (g) blanching, (h) cooling I, (i) cooling II, (j) IQF, (k) pengemasan, (l) pembekuan dan (m) penyimpanan. Salah satu tahapan penting yang sangat menentukan penerimaan produk oleh negara penerima adalah proses pencucian kontaminan (baik mikrobiologis dan residu pestisida). Proses pencucian memegang peranan penting dalam mengurangi kontaminan mikroba, yakni pada pencucian I menggunakan pada larutan klorin 100-150 ppm dan pencucian II dengan 175 ppm selama 10 menit. Hasil penelitian menunjukkan bahwa perlakuan klorin dioksida memiliki efek positif pada pengurangan pertumbuhan bakteri, khamir dan jamur pada buah dan sayuran (Chiabrando, et. al., 2017). Namun demikian sebenarnya sejak tahun 1997, penggunaan klorin sebagai zat antimicrobial, perlu mendapat perhatian, karena zat ini telah dilarang pemakaiannya oleh Uni Eropa sebagai zat anti mikroba bahan pangan. Hal ini akan sangat mungkin diberlakukan oleh Negara atau kawasan lain, mengingat perkembangan pakta perdagangan dunia yang mengarah pada aspek jaminan kualitas dan keamanan pangan yang komprehensip. Persyaratan ekspor edamame segar mencakup kandungan kontaminan mikroba berbahaya antara lain Salmonella $s p$, Shigella $s p$, dan $E$ coli, sedangkan residu berbahaya dengan komponen aktif yang tidak boleh melebihi ketentuan Batas Maksimum Residu (BMR). Kontaminan mikroba berbahaya ini umumnya berkisar antara $5,8 \times 10^{1}$ hingga $1,8 \times 10^{3} \mathrm{cfu} / \mathrm{g}$ (PT Mitratani 27 Jember, 2010). 

Abi Bakri, Wahyu Suryaningsih, Budi Hariono, Sri Hartatik. Perbaikan Kualitas dan Dekontaminasi Mikroba Kedelai Edamame Dengan Teknik Ozonated Water.

Salah satu perkembangan baru dalam bidang teknologi pengawetan pangan (food preservation) adalah penggunaan ozon, yang merupakan bentuk reaktif dari oksigen $\left(\mathrm{O}_{2}\right)$, dan mampu menghancurkan sejumlah besar partikelpartikel bahan beracun, melalui proses oksidasi, merupakan zat antimikrobia yang kuat, efektif digunakan untuk inaktivasi mikroorganisme, utamanya jamur (Trombete, et.al., 2016 Nooghi, et.al.,2016), selain juga perlakuan perlakuan ozon efektif mengurangi konsentrasi residu pestisida (Lozowicka B And Jankowska M., 2016, Lozowicka, et. al., 2016; Abdulateef, 2016). Beberapa penelitian ini membuktikan bahwa perlakuan teknik ozon adalah efektif untuk mengatasi cemaran mikrobiologi untuk berbagai jenis hasil tanaman seperti kacang Arab, Strawberry, buah kopi (Nooghi, et.al.,2016., Brandão,et.al.,2016). Inaktivasi bakteri oleh ozon terjadi karena proses lysing yakni pecahnya ikatan oksida dari dinding sel. Proses inaktivasi mikrobia dengan ozon didasarkan terutama pada daya oksidasinya yang sangat kuat, yang menyebabkan terurainya asam lemak dan membran sel dan sel makromolekul, seperti protein dan DNA (Naitoh, 1994).

Ozon atau $\mathrm{O}_{3}$ merupakan suatu gas tak berwarna yang mengembun membentuk suatu cairan biru pada suhu $-111^{\circ} \mathrm{C}$ dan akan membeku pada suhu $-192^{\circ} \mathrm{C}$ dengan warna biru kehitaman. Struktur dinyatakan sebagai suatu hybrid resonansi antara dua rumus Lewis yang ekuivalen dengan tiga atom $\mathrm{O}$ dengan satu ikatan rangkap. Sudut ikatan O-O-O adalah $117^{\circ}$, karakteristik ozon lainnya adalah pedas, tajam, tidak enak seperti pemutih chlor. Ozon secara alamiah terbentuk akibat penyinaran ultraviolet dari matahari, secara buatan dapat dibentuk dari peralatan berenergi tinggi, atau dibuat secara sintetis (Keenan,1999). Secara sederhana ozon dapat dibuat dengan melewatkan gas $\mathrm{O}_{2}$ pada sepasang keping elektroda bertegangan tinggi pada suhu rendah (kurang dari $20^{\circ} \mathrm{C}$ ) mengikuti persamaan reaksi :

$$
3 \mathrm{O}_{2 \text { (gas) }} \rightarrow 2 \mathrm{O}_{3 \text { (gas) }}
$$

Pada suhu kamar molekul ozon $\left(\mathrm{O}_{3}\right)$ cenderung tidak stabil dan mudah terurai menjadi $\mathrm{O}_{2}$ sehingga reaksi pembentukan ozon bersifat reversible.

Dari uraian di atas, disimpulkan bahwa ozon merupakan bahan antimikroba dan anti residu yang potensial untuk dikembangkan sebagai pengganti klorin dalam proses pencucian edamame. Oleh karena itu perlu dilakukan penelitian pencucian edamame segar dengan menggunakan ozon (ozonated water), yang secara teknis dan ekonomis dapat dipertanggungjawabkan. Tujuan dari kegiatan penelitian ini adalah: a) mengetahui pengaruh berbagai konsentrasi Ozon terhadap kualitas dan total mikroba edamame. b) membandingkan efektifitas teknik pencucian Ozonated Water dengan klorinasi dalam mempertahankan kualitas dan menghilangkan kontaminan mikroba, c) mendapatkan metoda pencucian Ozonated Water yang optimal dalam mempertahankan kualitas dan menghilangkan kontaminan mikroba edamame.

\section{BAHAN DAN METODE}

Bahan dan alat meliputi alat pencucian metoda ozonated water, timbangan analitis, berfungsi untuk berat bahan, perangkat alat uji analisis mikroorganisme TPC dan analisa Eschericia coli, dan edamame segar. Sampel edamame segar dicuci menggunakan bak pencuci dengan diberi perlakuan. Perlakuan terdiri dari 2 Faktor berupa Faktor pertama adalah ozonated water terdiri dari empat level konsentrasi ozon meliputi 0 ppm, 3 ppm, 6 ppm, dan 9 ppm masing-masing dengan waktu kontak 10 menit. Faktor kedua adalah Klorin terdiri 3 level, meliputi Klorin $0 \%, 100 \%$ dan $175 \%$. Semua perlakuan diulang 3 kali. Model matematika rancangan tersebut menurut Steel dan Torrie (1991):

Keterangan:

$$
\text { Yijk }=\mu+\alpha_{i}+\beta_{j}+\alpha \beta_{i j}+\varepsilon i j
$$

$\begin{array}{lll}\text { Yijk }= & \text { variabel respon akibat pengaruh taraf } \\ & & \text { konsentrasi Ozon ke-i dan taraf } \\ & \text { konsentrasi Klorin ke-j pada ulangan ke-k } \\ & = & \text { nilai tengah umum } \\ \mu & = & \text { pengaruh konsentrasi ozon level ke-i } \\ \boldsymbol{\alpha}_{\mathbf{i}} & \text { pengaruh konsentrasi Klorin level ke-j } \\ \boldsymbol{\alpha}_{\mathbf{i}} & \text { pengaruh interaksi antara konsentrasi ozon } \\ \boldsymbol{\alpha}_{\mathbf{i j}} & \text { ke-i dengan lama knsentrasi Klorin ke-j } \\ \text { Eij } & \text { pengaruh galat percobaan pada unit } \\ & \text { percobaan ke-k dalam kombinasi } \\ & \text { perlakuan ke-ij }\end{array}$

Pengujian statistik meliputi pengujian keragaman (Analysis of Variance) dengan uji $\mathrm{F}$ dan Uji statistik beda lanjut. variabel pengamatan terdiri dari a) mutu organoleptiknya meliputi uji hedonik warna, aroma, rasa manis dan uji mutu hedonik untuk rasa asing b) pemeriksaan mikrobiologis (total plate count dan e. coli).

\section{Analisis Uji Organoleptik}

a. Analisis Uji organoleptik meliputi uji kesukaan (hedonik) terhadap sampel edamame. Uji kesukaan (hedonik) menggunakan lima skala hedonik yaitu warna, aroma, dan rasa manis edamame. Kelima skala tersebut adalah $1=$ sangat tidak suka, $2=$ tidak suka, 3=biasa, 4=suka, 5=sangat suka. Uji dilakukan oleh 25 panelis agak terlatih. Khusus untuk pengamatan atribut Bau Asing diamati dengan uji Mutu Hedonik dengan Kriteria penilaian 1= Tercium Bau Asing sangat lemah, 2 = Tercium Bau 

Asing lemah, 3 = Tercium Bau Asing sedang, $4=$ Tercium bau asing agak kuat, dan $5=$ Tercium bau asing kuat. Hasil pengamatan data uji hedonic dilanjutkan dengan analisis statistic dengan Uji $\mathrm{F}$ dan Uji Beda Nyatja Jujur (BNJ).

\section{Analisis Mikroba dengan Total Plate Count (SNI 01-2891-1992).}

Penumbuhan mikroba dilakukan dengan menggunakan media Plate Count Agar (PCA) dengan cara $1 \mathrm{ml}$ inokulan diambil dengan pipet ke dalam cawan petri steril dan selanjutnya medium $P C A$ yang telah dingin (suhu kira-kira $37^{\circ} \mathrm{C}$ ) dituangkan ke dalam cawan petri steril sebanyak 12 $15 \mathrm{ml}$. Campuran tersebut dihomogenkan dengan cara cawan petri digerakkan dengan arah membentuk angka delapan. Setelah agar mengeras, cawan petri diinkubasikan dengan posisi terbalik pada suhu $35 \pm 1^{\circ} \mathrm{c}$ selama 24-48 jam. Jumlah bakteri ditentukan dengan metode hitungan cawan dan untuk melaporkan hasil analisis digunakan Standard Plate Count (SPC).

\section{HASIL DAN PEMBAHASAN}

Hasil penelitian meliputi : a) analisis mikrobiologi yaitu Total Plate Count (TPC) disajikan pada Gambar 1 dan b) Uji Organoleptik disajikan pada Gambar 2, 3, 4 dan 5.

\section{A. Analisis Mikroba dengan Total Plate Count} (TPC)

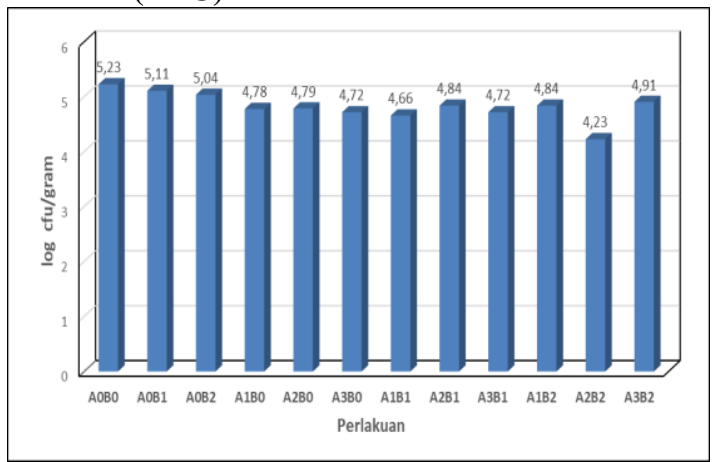

Gambar 1.Pengaruh Ozonated Water dan Klorin Terhadap Total Mikroorganisme (Metoda TPC)

Keterangan Perlakuan:

$\mathrm{A}_{0}=$ pencucian tanpa ozon

$\mathrm{A}_{1}=$ pencucian ozon dengan konsentrasi 3 ppm

$\mathrm{A}_{2}=$ pencucian ozon dengan konsentrasi $6 \mathrm{ppm}$

$\mathrm{A}_{3}=$ pencucian ozon dengan konsentrasi $9 \mathrm{ppm}$

$\mathrm{B}_{0}=$ pencucian tanpa klorin

$\mathrm{B}_{1}=$ pencucian klorin dengan konsentrasi $100 \mathrm{ppm}$

$\mathrm{B}_{2}=$ pencucian klorin dengan konsentrasi $175 \mathrm{ppm}$

Gambar 1 memperlihatkan bahwa perlakuan ozon dan klorin menghasilkan total mikroba kedelai edamame lebih rendah dibandingkan kontrol, perlakuan klorin dapat menurunkan total mikroba tetapi penurunan tidak sampai $1 \mathrm{log}$, berbeda halnya dengan perlakuan ozonated water baik tunggal ataupun kombinasi dengan klorin secara nyata dapat menurunkan total mikroba sampai 1 log. Perlakuan yang sangat efektif dalam menurunkan total mikroba adalah Kombinasi Perendaman ozon konsentrasi $6 \mathrm{ppm}$ dengan pencucian klorin konsentrasi 175 ppm. Senyawa ozon bersifat oksidatif kuat efektif menghambat pertumbuhan mikroorganisme utamanya jamur dan bakteri. Proses inaktivasi mikrobia dengan ozon didasarkan terutama pada daya oksidasinya yang sangat kuat, yang menyebabkan terurainya asam lemak dan membran sel dan sel makromolekul, seperti protein dan DNA (Trombete, et.al., 2016 Nooghi, et.al.,2016, dan Naitoh, 1994).

\section{B. Uji Organoleptik \\ 1.Warna}

Uji sensorik warna terhadap edamame yang diperlakukan dengan ozonated water d an klorin tertera pada Gambar 2.

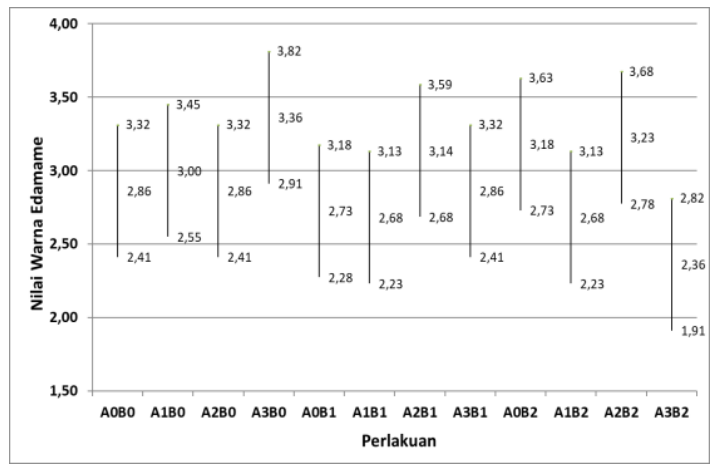

Gambar 2 Pengaruh Ozonated Water dan Klorin Terhadap Warna Edamame

Gambar 2 memperlihatkan bahwa berdasarkan Uji BNJ 0,05 nilai mutu warna edamame tidak mengalami penurunan dengan perlakuan ozon baik secara kombinasi dengan klorin ataupun perlakuan tunggal dibandingkan kontrol $\left(\mathrm{A}_{0} \mathrm{~B}_{0}\right)$. Nilai hedonik warna berbagai perlakuan Ozonated Water tidak berbeda nyata perlakuan Klorin dengan skor sekitar 3 dengan kriteria nilai warna kurang disukai sampai biasa. Nilai mutu warna edamame tertinggi dihasilkan dari pencucian ozon tunggal dengan konsentrasi 9 ppm dengan skor 3,36 atau kriteria biasa sampai disukai. Hal ini menunjukkan bahwa baik perlakuan Ozon ataupun klorin secara tunggal ataupun kombinasi tidak memberikan pengaruh yang berarti terhadap perubahan warna edamame. $।$ 

Abi Bakri, Wahyu Suryaningsih, Budi Hariono, Sri Hartatik. Perbaikan Kualitas dan Dekontaminasi Mikroba Kedelai Edamame Dengan Teknik Ozonated Water.

\section{Aroma Edamame}

Uji Organoleptik aroma terhadap edamame yang diperlakukan dengan ozonated water dan klorin tertera pada Gambar 3.

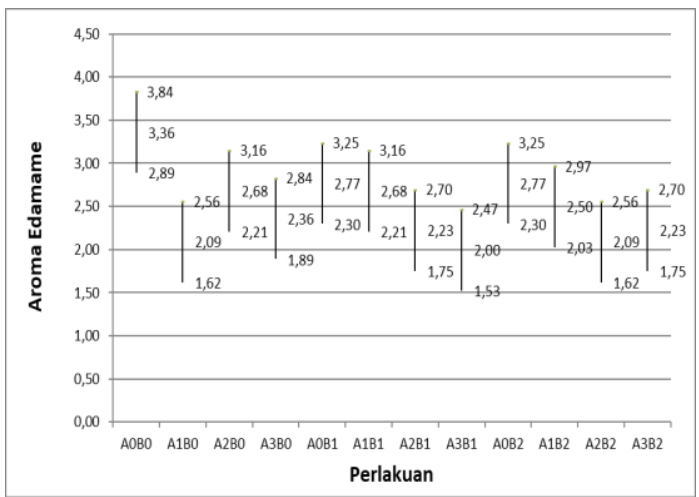

Gambar 3 Pengaruh Ozonated Water Dan Klorin Terhadap Aroma Edamame.

Gambar 3 memperlihatkan bahwa berdasarkan uji BNJ 0,05 perlakuan ozonated water tunggal dan kombinasi dengan klorin menunjukkan nilai mutu aroma edamame lebih rendah dari pada kontrol, sedangkan efek klorin secara tunggal relative tidak berbeda nyata dengan control. Nilai aroma edamame pada perlakuan Ozon tunggal ataupun kombinasi dengan klorin berkisar antara 2,00 sampai dengan 2,77 ini menunjukkan kriteria aroma tidak disukai sampai aroma biasa, sedangkan untuk kontrol 3,36 berarti menunjukkan kriteria aroma biasa sampai dengan aroma agak disuka. Hal ini menunjukkan pada perlakuan konsentrasi Ozon water secara tunggal ataupun kombinasi dengan Klorin ada pengaruh kimiawi yang menurunkan kualitas aroma edamame.

\section{Rasa Manis}

Uji sensorik rasa manis terhadap edamame yang diperlakukan dengan ozonated water dan klorin tertera pada Gambar 4.

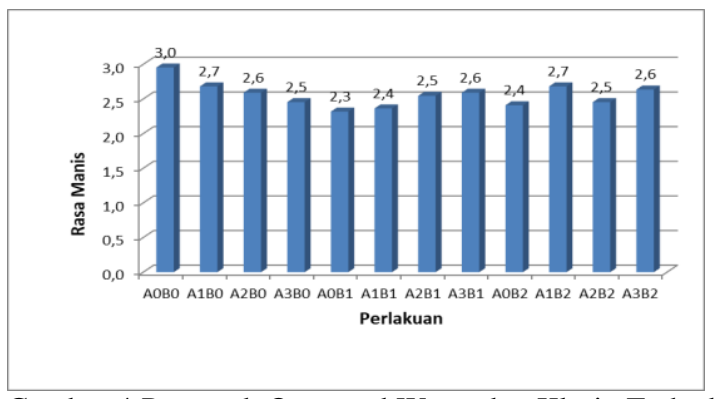

Gambar 4 Pengaruh Ozonated Water dan Klorin Terhadap Rasa Manis Edamame

Gambar 4 memperlihatkan bahwa hasil Analisis of Varians menunjukkan bahwa nilai mutu rasa manis edamame pada semua perlakuan baik pengaruh Ozonated Water, Klorin secara kombinasi ataupun tunggal serta dibandingkan Kontrol juga semua memperlihatkan kualitas rasa manis yang relatif sama atau tidak terdapat perbedaan rasa manis yang berarti. Hal ini memperlihatkan bahwa penggunaan Ozon ataupun Klorin secara tunggal ataupun kombinasi tidak menyebabkan perubahan kualitas Rasa Manis Edamame.

\section{Bau Asing}

Uji Organoleptik untuk bau asing terhadap edamame yang diperlakukan dengan ozonated water dan klorin tertera pada Gambar 5.

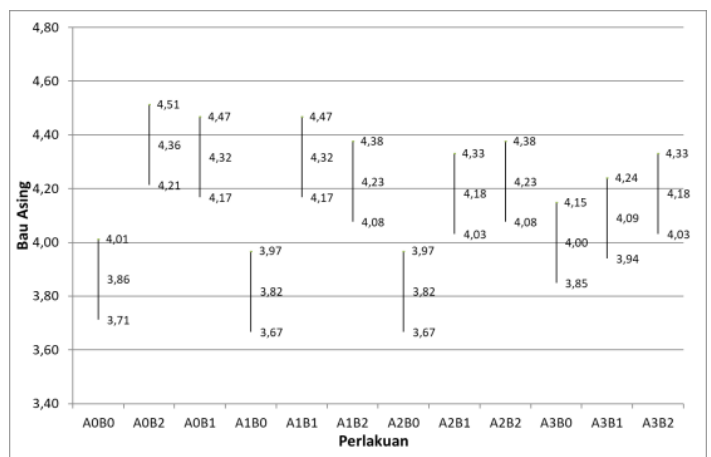

Gambar 5. Pengaruh Ozonated Water dan Klorin Terhadap Bau Asing Edamame

Hasil uji BNJ 0,05 terlihat bahwa perlakuan Ozonated Water dan Kontrol memperlihatkan terciumnya bau asing relatif lebih rendah dibandingkan perlakuan Klorin baik yang tunggal ataupun yang kombinasi dengan Ozon, yaitu pada kisaran nilai $4-4,36$ dengan kriteria tercium bau asing dengan intensitas agak kuat sampai kuat, hal ini menunjukkan bahwa kontribusi bau asing ataupun bau kimia oleh Ozon relative tidak berarti dan efeknya sama dengan Kontrol dengan kisaran nilai 3,82 -3,86 dengan kriteria intensitas bau asing sedang sampai agak kuat.

\section{KESIMPULAN}

Berdasarkan hasil pengamatan dan analisis data disimpulkan sebagai berikut: a) perlakuan Ozon dan klorin dapat menurunkan kandungan total mikroba edamame dibandingkan kontrol, dan perlakuan ozon lebih efektif dalam menurunkan total mikroba dibandingkan klorin, b) perlakuan yang sangat efektif dalam menurunkan total mikroba adalah Kombinasi Perendaman ozon konsentrasi 6 ppm dengan pencucian klorin konsentrasi 175 ppm, c) perlakuan Ozon ataupun Klorin tidak berpengaruh terhadap nilai warna dan rasa manis secara hedonik pada edamame, d) perlakuan Ozon dapat menurunkan nilai aroma edamame dibandingkan dengan kontrol dan perlakuan klorin, walaupun 



\section{Jurnal Ilmiah INOVASI, Vol. 18 No. 1 Edisi Januari April 2018, ISSN 1411-5549}

sebenarnya perlakuan Ozon tidak memberikan kontribusi bau asing terhadap edamame.

\section{DAFTAR PUSTAKA}

[1] Abdulateef, Z.A, 2016. Assessment the availability of ozonated water on the bioavailability of deltamethrin in treated sheep's meat., Int. J. Adv. Res. Biol. Sci.3(11):

[2] Brandão F. J. B., Biaggioni M.A. M., Sperotto. F. C. S.,Fujita. E, Santos P L. \& Da Silva M. A. P.,2016., Ozonated water in the post-harvest treatment of coffee fruits ., R. Bras. Eng. Agríc. Ambiental, v.20, n.9.

[3] Carletti.L., Botondi.R., Moscetti. R., Stella.E., Monarca.D., Cecchin.M \& Massantini.R., .,2013., Use of ozone in sanitation and storage of fresh fruits and vegetables., Journal of Food, Agriculture \& Environment Vol.11 (3\& 4).

[4] Chiabrando, V., Peano, C. \& Giacalone, G., 2017., The efficacy of different postharvest treatments on physico-chemical characteristics, bioactive components and microbiological quality of fresh blueberries during storage period. Food Research 1 (6) .[5] Keenan, R. 1999. Stabilized leachates: ozoneactivated carbon treatment and kinetics. J. Science Direct. 37, 4823-4834

[6] Kim C, Torres A, Xu. Y., Kaseloo P., Nguyen L., Awan Z., Rutto L., Sismour E., Jiang GL., Kering M.,, Wynn C.,, Stein R., \& Pao S., 2017., Role of Steam Blanching and Vacuum Packaging on the Physical and Microbiological Quality of Fresh Vegetable Soybean (Edamame) During Storage Austin Food Sci 2(1): id1029.

[7] Lozowicka B., Jankowska M., IHrynko I., \& Kaczynski P.,2016., Removal of 16 pesticide residues from Strawberries by washing with tap and ozone water, ultrasonic cleaning and boiling., Environ Monit Assess 188: 51.

[8] Łozowicka B And Jankowska M., 2016., Comparison Of The Effects Of Water And Thermal Processing On Pesticide Removal In Selected Fruit And Vegetables., Journal of Elementology., 21(1): 99-111

[9] Naitoh, S.Y. 1994. Studies on utilization of ozone in food preservation: V. Changes in microflora of ozonetreated cereals, grain, peas, and spices during storage. J. Japanese Soc. Food Sci. Technol. 35:69-77

[10] Nooghi E.M, Jafari AA.,Khavidak SS and Jafari H.,,2016.,Impacts of dehydroacetic acid and ozonated water on Aspergillus flavus Colonization and AflatoxinB1 Accumulation in Iranian Pistachio. J. of Food Quality and Hazards Control 3.

[11] Ramirez, G.A., C.R. Yezak. Jr., J.S. Jeffrey, T.D. Rogers, G.D. Hithchens, B.M Hargis. 1994. Potential efficacy of ozonation as a Salmonella decontamination methods in broiler carcasses. Poul. Sci. Abztract p. 21.

[12] Restaino, L., E.W. Frampton, J.B Hemphill, P. Palnikar. 1995. Efficacy of ozonated water against various food-related microorganisms. Appl. Environ. Microbiol, 61:3471-3475

[13] Silva da, M.A., Gibbs, P.A, Kirby, R M. 1998. Sensorial and Microbial Effects of Gaseous Ozone on Fresh Scad(Trachurus trachurus) J. App. Micro. 84: 802- 810.

[14] Sumiati, 2006, Mempelajari Metode Pembekuan dan Thawing Pada Proses Pembuatan Edamame Goreng, Laporan Topik Perorangan, Politeknik Negeri Jember. Jember.

[15] Trombete, F. M., Freitas-Silva, O.,Saldanha, T., Venâncio, A. A. and Fraga, M. E.., 2016., Ozone against mycotoxins and pesticide residues in food: Current applications and perspectives., International Food Research Journal 23(6):

[16] Venosa, A.D. 1972. Ozone as a water and wastewater disinfectan, p. 95. In F.L. Evans (ed) Ozone in water and wastewater treatmen. Ann Arbor Science Publisher Inc., Ann Arbor, Mich.

[17] Zeipiņa S., Alsiņa I., \& Lepse L. 2017., Insight In Edamame Yield And Quality Parameters: A Review, Research For Rural Development ., Volume 2.

[18] Zhang,Q., Yansheng Li Y., Chin KL., Qi. Y., 2017., Vegetable soybean: seed composition and production research.,Italian Journal of Agronomy. 

